The Chittagong Univ. J. B. Sci., Vol. 6(1 \&2):11-25, 2011.

\title{
EFFECTS OF SOME INDIGENOUS PLANT SEED EXTRACTS ON THE HAEMATOLOGY OF A PREDATORY FISH SINGHI HETEROPNEUSTES FOSSILIS (BLOCH)
}

\author{
MUNIRA NASIRUDDIN ${ }^{1}$, MOHAMMAD ALI AZADI ${ }^{1 *}$, MONIKA RAHMAN $^{1}$ AND \\ ISRAT ARA SHAZIA RAHMAN ${ }^{1}$ \\ Department of Zoology, University of Chittagong, Chittagong 4331, Bangladesh
}

\begin{abstract}
Haemolytic effects of different extracts of five indigenous plant seeds viz. Datura innoxia (Mill) (Shada Dhutra), Clerodendrum viscosum (Vent.) (Vat), Amoora rohituka (Roxb.) Wt. ct. Arnott (Pitraj), Acacia auriculiformis A. Cunn. Ex. Benth. (Akashmoni) and Pongamia pinnata (L.) Pierre (Karinja) were studied upon a predatory fish, Singhi, Heteropneustes fossilis (Bloch) under laboratory conditions. Toxicants inducing effects on the blood parameters included decreased RBC and WBC counts, low haemoglobin percentage and decreased PCV (packed cell volume), MCV (mean corpuscular volume) and $\mathrm{MCH}$ (mean corpuscular haemoglobin). Haemolysis action included shrunken or swollen RBCs, granulated nuclei of RBCs and pyknotic nuclei of WBCs, clumping of RBCs and syncitium of RBC matrix. Damage of blood cells with absolute ethyl alcohol extract was most pronounced with all of the seed extracts. The order of toxicity of the five seed extracts on the blood parameters of Singhi was: $D$. innoxia $<A$. auriculaerformis $<P$. pinnata $<C$. viscosum $<A$. rohituka seed extracts. On the basis of haemolysis the toxicity was: A. rohituka $>C$. viscosum $>$ $P$. pinnata $>D$. innoxia $>A$. auriculiformis seed extracts.
\end{abstract}

Key words: Seed extracts, Haemolytic effects, Blood parameters, Blood cell haemolysis, $H$. fossilis

\section{INTRODUCTION}

The haematological assessment is a motive to prove any disturbances and environmental stress on fishes. The study of haematological effects of toxic extracts on the blood parameters and blood cells of fishes is a consequence of strenuous attempt which guides to comprehend the impact of toxicants on fishes. The changes in the characteristics of blood cells are important diagnostic indicators (Blaxhall 1972) of environmental stress on fish.

*Corresponding author: email: maazadi@yahoo.com 
MUNIRA NASIRUDDIN et al.

Information about the effects of toxicants on fish blood are available from the studies of Srivastava and Agarwal (1979), Agrawal et al. (1979, 1985), Pandey et al. (1981), Goel and Gupta (1985), Dheer et al. (1986), Sen et al. (1992), Wepner et al. (1992), Allen (1993), Vosyliene (1996, 1999), Hymavathi and Rao (2000) and Ashraf et al. (2003). However, only a few works have been carried out on the effects of plant extracts in fish haematology. Research on this aspect were carried out by Bhatt and Farswan (1992), Agbon et al. (2002), Omoniyi et al. (2002) and Fafioye et al. (2004). At home Nasiruddin et al. (2001, 2002) studied the haematological effects of Cassia siamea, Datura metel, Albizzia lebbeck and Camellia sinensis seed or seed cake extracts on the blood of Singhi (Heteropneustes fossilis) and Taki (Channa punctatus).

The present paper deals with the effects of Datura innoxia (Mill) (Shada Dhutra), Clerodendrum viscosum (Vent.) (Vat), Amoora rohituka (Roxb.) Wt. Ct. Arnot (Pitraj), Acacia auriculiformis (A. Cunn. Ex Benth.) (Akashmoni) and Pongamia pinnata (L.) Pierre (Karinja) seed extracts on the basic parameters of haematology and blood cells of Singhi, Heteropneustes fossilis (Bloch). The aim of the present study was to investigate the changes in the haematological parameters and blood cells, and the extent of the effect of the five indigenous plant seed extracts on the haematology of Singhi fish.

\section{MATERIALS AND METHODS}

\section{Collection of seeds and fish}

Seeds of D. innoxia were collected from Bogra district and seeds of $C$. viscosum, A. rohituka, A. auriculiformis and $P$. pinnata from Chittagong University campus. Every set of the experimental fishes were collected from Chittagong city markets, brought to the laboratory and acclimatized for 4-5 hours without any food in experimental aquaria.

\section{Preparation of the doses}

Dry seeds were crushed in a mortar with a pestle, grinded in an electric blender and then sieved (mesh size $0.0025 \mathrm{~mm}^{2}$ ). Ten gram of the fine seed powder was mixed with $100 \mathrm{ml}$ of either distilled water, 50\% ethyl alcohol or absolute ethyl alcohol solvents in a conical flask and then shaken vigorously in a magnetic stirrer for 4-5 hours for extraction. The extracted solvent was then filtered through fine muslin and the filtrate was the 'stock solution' of the experiments which was prepared on the same day of the experiments. The test doses were calculated from the stock solution by appropriate dilution (APHA 1976). 
EFFECTS OF SOME INDIGENOUS PLANT SEED EXTRACTS ON THE HAEMATOLOGY

OF A PREDATORY FISH SINGHI HETEROPNEUSTES FOSSILIS (BLOCH)

\section{Bioassays}

The bioassays were run in a series of glass aquaria each containing five litres of tap water and toxicant. Five concentrations of each extract replicated twice were bioassayed. In each concentration five active test fishes were released and kept in the media for 24 hours. A control set with only tap water was similarly maintained.

\section{Blood analysis}

Blood films from both control and treated (middle dose of each extract) were collected on clean greaseless slides and stained in Leishman's stain to observe the changes in the blood cells. The total numbers of RBCs and WBCs were estimated using the methods of Raphael (1983). Haemoglobin (Hb) and packed cell volume (PCV) were determined by conventional method. The mean corpuscular volume (MCV) and mean corpuscular haemoglobin $(\mathrm{MCH})$ were evaluated following Bhatt and Farswan (1992).

Statistical analysis and microphotography

The ' $t$ ' test was applied to determine the significance between control versus treated blood parameters of the fish and also to assess the degree of haemolytic property of the plant toxicants. The photomicrographs were taken with a compound microscope with photographic attachment under 10x100 oil immersion magnification.

\section{RESULTS AND DISCUSSION}

Haemolytic effects of the seed extracts on the blood parameters of H. fossilis

The haematological parameters were studied only in the middle dose of each extract and compared with the control. These sublethal concentrations of the extracts of the seeds induced changes in the blood parameters of $H$. fossilis. Red blood cells (RBC), white blood cells (WBC), haemoglobin content ( $\mathrm{Hb}$ gm and $\%)$ and packed cell volume (PCV) decreased whilst the absolute parameters i.e. the mean cell volume (MCV) and mean corpuscular haemoglobin $(\mathrm{MCH})$ also decreased. The comparative data of haematological analysis and the results of $t-$ test done between the parameters of control versus treated fishes are shown in Tables $1 \& 2$.

With the extracts of $D$. innoxia seeds the total counts of RBC, WBC, $\mathrm{Hb}$ (gm \& \%), PCV, MCV and MCH decreased in the $2000 \mathrm{ppm}$ dose of distilled water extract. In all cases, t-test showed significant decrease in comparison with 
the control. 1500 ppm of 50\% ethyl alcohol and 1000 ppm of absolute ethyl alcohol extracts also decreased the mean values of all the blood parameters significantly in comparison with the control. The effects of $C$. viscosum seed extracts on the blood parameters showed that with all the three extracts the values of all the blood parameters decreased, the middle dose being $150 \mathrm{ppm}$ for distilled water, $100 \mathrm{ppm}$ for $50 \%$ ethyl alcohol and $50 \mathrm{ppm}$ for absolute ethyl alcohol extracts. The treatment results showed significant values in $\mathrm{RBC}, \mathrm{Hb}$ (gm \& \%), $\mathrm{PCV}, \mathrm{MCV}$ and $\mathrm{MCH}$ values but the WBC showed insignificant values. The 50 ppm of distilled water, 25 ppm of $50 \%$ ethyl alcohol and 10 ppm of absolute ethyl alcohol extracts of $A$. rohituka seeds decreased the mean values of $\mathrm{RBC}, \mathrm{Hb}$ (gm $\& \%), \mathrm{PCV}, \mathrm{MCV}$ and $\mathrm{MCH}$ values gradually and significantly compared with the control values excepting the WBC values. It was clear from the results of distilled water (750 ppm), 50\% ethyl alcohol (500 ppm) and absolute ethyl alcohol $(250 \mathrm{ppm})$ extracts of $A$. auriculiformis seeds that the blood parameters were affected and in all cases the values decreased significantly from the control. The total counts of RBC, WBC, Hb (gm \& \%), PCV, MCV and MCH values of distilled water $(250 \mathrm{ppm}), 50 \%$ ethyl alcohol $(150 \mathrm{ppm})$ and absolute ethyl alcohol $(50 \mathrm{ppm})$ extracts of $P$. pinnata seeds decreased and t-test showed significant relation between control and treated parameters excepting the WBC parameters of distilled water and 50\% ethyl alcohol extracts. 


\begin{abstract}
EFFECTS OF SOME INDIGENOUS PLANT SEED EXTRACTS ON THE HAEMATOLOGY OF A PREDATORY FISH SINGHI HETEROPNEUSTES FOSSILIS (BLOCH)
\end{abstract}

TABLE 1: MEAN VALUES \pm SE OF RED BLOOD CELLS (RBC), WHITE BLOOD CELLS (WBC), HAEMOGLOBIN (HB), PACKED CELL VOLUME (PCV), MEAN CORPUSCULAR VOLUME (MCV) AND MEAN CORPUSCULAR HAEMOGLOBIN (MCH) OF CONTROL AND SEED EXTRACT TREATED H. FOSSILIS BLOOD.(D.W.= DISTILLED WATER, 50\% E.A. $=50 \%$ ETHYL ALCOHOL, ABS. E.A.=ABSOLUTE ETHYL ALCOHOL EXTRACTS).

\begin{tabular}{|c|c|c|c|c|c|c|c|c|}
\hline Seed & Extract & $\begin{array}{c}\mathrm{RBC} \\
\left(\mathrm{x} 10^{6} / \mathrm{mm}^{3}\right)\end{array}$ & $\begin{array}{c}\text { WBC } \\
\left(\times 10^{3} / \mathrm{mm}^{3}\right)\end{array}$ & $\begin{array}{l}\mathrm{Hb} \\
(\%)\end{array}$ & $\begin{array}{c}\mathrm{Hb} \\
(\mathrm{gm} / \mathrm{dl})\end{array}$ & $\begin{array}{c}\mathrm{PCV} \\
(\mathrm{gm} / \mathrm{dl})\end{array}$ & $\begin{array}{l}\mathrm{MCV} \\
\left(\mu / \mathrm{m}^{3}\right)\end{array}$ & $\begin{array}{c}\mathrm{MCH} \\
(\mu / \mathrm{mg})\end{array}$ \\
\hline & Control & $3.36 \pm 0.14$ & $4.48 \pm 0.12$ & $106.80 \pm 2.10$ & $15.62 \pm 0.28$ & $46.86 \pm 0.85$ & $139.91 \pm 4.27$ & $318.76 \pm 8.99$ \\
\hline$D a$ & D. W. & $2.96 \pm 0.05$ & $2.72 \pm 0.08$ & $66.00 \pm 1.30$ & $9.12 \pm 0.06$ & $27.36 \pm 0.18$ & $93.24 \pm 0.86$ & $224.00 \pm 0.95$ \\
\hline \multirow[t]{2}{*}{ innoxia } & $50 \%$ E.A. & $2.52 \pm 0.03$ & $2.34 \pm 0.08$ & $53.80 \pm 1.07$ & $7.70 \pm 0.23$ & $23.10 \pm 0.68$ & $91.66 \pm 3.16$ & $214.73 \pm 4.44$ \\
\hline & Abs.E.A. & $2.18 \pm 0.06$ & $2.26 \pm 0.20$ & $44.80 \pm 2.20$ & $6.54 \pm 0.27$ & $19.62 \pm 0.82$ & $89.99 \pm 1.71$ & $205.32 \pm 5.13$ \\
\hline \multirow{4}{*}{$\begin{array}{l}\text { Clerodendrum } \\
\text { viscosum }\end{array}$} & Control & $3.45 \pm 0.36$ & $2.40 \pm 0.10$ & $111.20 \pm 1.50$ & $16.14 \pm 0.19$ & $48.42 \pm 0.57$ & $138.73 \pm 0.23$ & $318.59 \pm 1.32$ \\
\hline & D. W. & $2.39 \pm 0.14$ & $1.98 \pm 0.21$ & $46.40 \pm 1.96$ & $9.64 \pm 0.26$ & $19.80 \pm 0.70$ & $83.39 \pm 3.28$ & $195.00 \pm 6.39$ \\
\hline & $50 \%$ E.A. & $2.19 \pm 0.09$ & $1.94 \pm 0.09$ & $42.00 \pm 2.88$ & $6.02 \pm 0.39$ & $18.00 \pm 1.13$ & $81.56 \pm 2.57$ & $190.82 \pm 6.78$ \\
\hline & Abs.E.A. & $2.11 \pm 0.12$ & $1.58 \pm 0.20$ & $38.20 \pm 2.46$ & $5.64 \pm 0.39$ & $16.92 \pm 1.16$ & $79.68 \pm 1.03$ & $180.05 \pm 1.54$ \\
\hline \multirow{4}{*}{$\begin{array}{l}\text { Amoora } \\
\text { rohituka }\end{array}$} & Control & $3.35 \pm 0.05$ & $2.84 \pm 0.22$ & $100.86 \pm 1.75$ & $15.84 \pm 0.25$ & $47.52 \pm 0.74$ & $138.78 \pm 0.85$ & $317.14 \pm 1.77$ \\
\hline & D. W. & $2.15 \pm 0.07$ & $1.76 \pm 0.21$ & $39.80 \pm 1.16$ & $5.78 \pm 0.20$ & $17.34 \pm 0.60$ & $81.16 \pm 1.25$ & $185.27 \pm 1.71$ \\
\hline & $50 \%$ E.A. & $2.11 \pm 0.09$ & $1.52 \pm 0.25$ & $37.20 \pm 1.16$ & $5.48 \pm 0.28$ & $16.38 \pm 0.79$ & $77.63 \pm 1.48$ & $176.06 \pm 3.75$ \\
\hline & Abs.E.A. & $2.01 \pm 0.03$ & $1.38 \pm 0.19$ & $35.40 \pm 1.03$ & $5.14 \pm 0.07$ & $15.42 \pm 0.22$ & $76.66 \pm 0.81$ & $175.87 \pm 3.50$ \\
\hline \multirow{4}{*}{$\begin{array}{l}\text { Acacia } \\
\text { auriculae- } \\
\text { formis }\end{array}$} & Control & $3.58 \pm 0.10$ & $3.48 \pm 0.09$ & $109.20 \pm 1.59$ & $15.88 \pm 0.26$ & $47.64 \pm 0.78$ & $133.48 \pm 4.02$ & $305.96 \pm 9.04$ \\
\hline & D. W. & $2.77 \pm 0.05$ & $2.64 \pm 0.08$ & $58.40 \pm 1.63$ & $8.34 \pm 0.18$ & $25.02 \pm 0.53$ & $90.27 \pm 1.90$ & $210.50 \pm 5.34$ \\
\hline & $50 \%$ E.A. & $2.56 \pm 0.05$ & $2.32 \pm 0.18$ & $51.80 \pm 0.97$ & $7.42 \pm 0.16$ & $22.26 \pm 0.47$ & $86.50 \pm 1.23$ & $200.80 \pm 4.42$ \\
\hline & Abs. E.A. & $2.33 \pm 0.11$ & $2.08 \pm 0.22$ & $44.40 \pm 2.32$ & $6.40 \pm 0.25$ & $19.20 \pm 0.76$ & $82.51 \pm 0.71$ & $190.44 \pm 2.64$ \\
\hline \multirow{4}{*}{$\begin{array}{l}\text { Pongamia } \\
\text { pinnata }\end{array}$} & Control & $3.36 \pm 0.07$ & $2.86 \pm 0.22$ & $107.20 \pm 2.15$ & $15.62 \pm 0.28$ & $46.86 \pm 0.85$ & $138.30 \pm 1.10$ & $316.97 \pm 2.13$ \\
\hline & D. W. & $2.59 \pm 0.11$ & $2.20 \pm 0.06$ & $52.80 \pm 2.27$ & $9.84 \pm 0.36$ & $22.44 \pm 1.07$ & $86.55 \pm 0.97$ & $203.86 \pm 1.95$ \\
\hline & $50 \%$ E.A. & $2.48 \pm 0.08$ & $1.90 \pm 0.07$ & $49.20 \pm 1.93$ & $7.02 \pm 0.32$ & $21.06 \pm 0.97$ & $84.78 \pm 1.09$ & $198.27 \pm 1.43$ \\
\hline & Abs.E.A. & $2.25 \pm 0.03$ & $1.50 \pm 0.14$ & $43.00 \pm 2.55$ & $6.95 \pm 0.38$ & $18.48 \pm 1.20$ & $81.23 \pm 2.97$ & $190.52 \pm 3.90$ \\
\hline
\end{tabular}


MUNIRA NASIRUDDIN et al.

TABLE 2 : RESULT OF ' $T$ ' TEST BETWEEN THE MEANS OF CONTROL AND SEED EXTRACT TREATED BLOOD PARAMETERS OF $H$. FOSSILIS (P VALUES INDICATE SIGNIFICANCE AT 0.01 LEVEL) (D.W = DISTILLED WATER, 50\% E.A. $=50 \%$ ETHYL ALCOHOL AND ABS. E.A.= ABSOLUTE ETHYL ALCOHOL EXTRACTS).

\begin{tabular}{|c|c|c|c|c|c|c|c|c|}
\hline \multirow[t]{2}{*}{ Seed } & \multirow[t]{2}{*}{ Control vs treated } & \multirow[t]{2}{*}{$\mathrm{RBC}$} & \multirow[t]{2}{*}{ WBC } & \multicolumn{2}{|c|}{ Haemoglobin } & \multirow[t]{2}{*}{$\mathrm{PCV}$} & \multirow[t]{2}{*}{$\mathrm{MCV}$} & \multirow[t]{2}{*}{$\mathrm{MCH}$} \\
\hline & & & & $\%$ & $\mathrm{gm}$ & & & \\
\hline \multirow{6}{*}{ Datura innoxia } & Control vs & 6.61 & 11.92 & 23.90 & 2.27 & 22.60 & 10.73 & 10.39 \\
\hline & D. W. & $\mathrm{P}<0.01$ & $\mathrm{P}<0.01$ & $\mathrm{P}<0.01$ & $\mathrm{P}>0.01$ & $\mathrm{P}<0.01$ & $\mathrm{P}<0.01$ & $\mathrm{P}<0.01$ \\
\hline & Control vs & 6.05 & 14.50 & 22.50 & 21.83 & 21.85 & 9.09 & 11.29 \\
\hline & $50 \%$ E. A. & $\mathrm{P}<0.01$ & $\mathrm{P}<0.01$ & $\mathrm{P}<0.01$ & $\mathrm{P}<0.01$ & $\mathrm{P}<0.01$ & $\mathrm{P}<0.01$ & $\mathrm{P}<0.01$ \\
\hline & Control vs & 7.50 & 9.29 & 20.39 & 23.14 & 23.15 & 10.86 & 10.95 \\
\hline & Abs. E. A. & $\mathrm{P}<0.01$ & $\mathrm{P}<0.01$ & $\mathrm{P}<0.01$ & $\mathrm{P}<0.01$ & $\mathrm{P}<0.01$ & $\mathrm{P}<0.01$ & $\mathrm{P}<0.01$ \\
\hline \multirow{6}{*}{$\begin{array}{l}\text { Clerodendrum } \\
\text { viscosum }\end{array}$} & Control vs & 7.87 & 1.82 & 26.25 & 29.76 & 31.71 & 16.81 & 18.95 \\
\hline & D. W. & $\mathrm{P}<0.01$ & $\mathrm{P}>0.01$ & $\mathrm{P}<0.01$ & $\mathrm{P}<0.01$ & $\mathrm{P}<0.01$ & $\mathrm{P}<0.01$ & $\mathrm{P}<0.01$ \\
\hline & Control vs & 13.92 & 3.47 & 21.32 & 23.38 & 24.00 & 22.20 & 18.51 \\
\hline & $50 \%$ E. A. & $\mathrm{P}<0.01$ & $\mathrm{P}>0.01$ & $\mathrm{P}<0.01$ & $\mathrm{P}<0.01$ & $\mathrm{P}<0.01$ & $\mathrm{P}<0.01$ & $\mathrm{P}<0.01$ \\
\hline & Control vs & 10.77 & 3.67 & 25.38 & 24.46 & 24.40 & 56.71 & 64.50 \\
\hline & Abs. E. A. & $\mathrm{P}<0.01$ & $\mathrm{P}>0.01$ & $\mathrm{P}<0.01$ & $\mathrm{P}<0.01$ & $\mathrm{P}<0.01$ & $\mathrm{P}<0.01$ & $\mathrm{P}<0.01$ \\
\hline \multirow{6}{*}{ Amoora rohituka } & Control vs & 14.83 & 3.46 & 32.81 & 31.73 & 31.69 & 38.04 & 53.64 \\
\hline & D. W. & $\mathrm{P}<0.01$ & $\mathrm{P}>0.01$ & $\mathrm{P}<0.01$ & $\mathrm{p}<0.01$ & $\mathrm{P}<0.01$ & $\mathrm{P}<0.01$ & $\mathrm{P}<0.01$ \\
\hline & Control vs & 13.08 & 3.99 & 26.25 & 27.91 & 28.78 & 35.75 & 35.07 \\
\hline & $50 \%$ E. A. & $\mathrm{P}<0.01$ & $P>0.01$ & $\mathrm{P}<0.01$ & $\mathrm{P}<0.01$ & $\mathrm{P}<0.01$ & $\mathrm{P}<0.01$ & $\mathrm{P}<0.01$ \\
\hline & Control vs & 25.83 & 4.97 & 36.07 & 41.65 & 41.62 & 52.65 & 36.04 \\
\hline & Abs. E. A. & $\mathrm{P}<0.01$ & $\mathrm{P}>0.01$ & $\mathrm{P}<0.01$ & $\mathrm{P}<0.01$ & $\mathrm{P}<0.01$ & $\mathrm{P}<0.01$ & $\mathrm{P}<0.01$ \\
\hline \multirow{6}{*}{$\begin{array}{l}\text { Acacia } \\
\text { auriculiformis }\end{array}$} & Control vs & 6.98 & 6.81 & 22.29 & 24.04 & 23.99 & 9.71 & 9.10 \\
\hline & D. W. & $\mathrm{P}<0.01$ & $\mathrm{P}<0.01$ & $\mathrm{P}<0.01$ & $\mathrm{P}<0.01$ & $\mathrm{P}<0.01$ & $\mathrm{P}<0.01$ & $\mathrm{P}<0.01$ \\
\hline & Control vs & 8.92 & 5.81 & 30.78 & 27.98 & 27.95 & 11.18 & 10.45 \\
\hline & $50 \%$ E. A. & $\mathrm{P}<0.01$ & $\mathrm{P}<0.01$ & $\mathrm{P}<0.01$ & $\mathrm{P}<0.01$ & $\mathrm{P}<0.01$ & $\mathrm{P}<0.01$ & $\mathrm{P}<0.01$ \\
\hline & Control vs & 8.37 & 25.70 & 23.06 & 26.13 & 26.08 & 12.49 & 12.27 \\
\hline & Abs. E. A. & $\mathrm{P}<0.01$ & $\mathrm{P}<0.01$ & $\mathrm{P}<0.01$ & $\mathrm{P}<0.01$ & $\mathrm{P}<0.01$ & $\mathrm{P}<0.01$ & $\mathrm{P}<0.01$ \\
\hline \multirow{6}{*}{$\begin{array}{l}\text { Pongamia } \\
\text { pinnata }\end{array}$} & Control vs & 6.12 & 2.90 & 17.40 & 17.90 & 17.87 & 35.22 & 39.12 \\
\hline & D. W. & $\mathrm{P}<0.01$ & $\mathrm{P}>0.01$ & $\mathrm{P}<0.01$ & $\mathrm{P}<0.01$ & $\mathrm{P}<0.01$ & $\mathrm{P}<0.01$ & $\mathrm{P}<0.01$ \\
\hline & Control vs & 8.25 & 4.16 & 20.04 & 19.99 & 19.97 & 34.48 & 46.25 \\
\hline & $50 \%$ E. A. & $\mathrm{P}<0.01$ & $\mathrm{P}>0.01$ & $\mathrm{P}<0.01$ & $\mathrm{P}<0.01$ & $\mathrm{P}<0.01$ & $\mathrm{P}<0.01$ & $\mathrm{P}<0.01$ \\
\hline & Control vs & 9.96 & 5.20 & 19.23 & 20.31 & 19.20 & 18.01 & 28.42 \\
\hline & Abs. E. A. & $\mathrm{P}<0.01$ & $\mathrm{P}<0.01$ & $\mathrm{P}<0.01$ & $\mathrm{P}<0.01$ & $\mathrm{P}<0.01$ & $\mathrm{P}<0.01$ & $\mathrm{P}<0.01$ \\
\hline
\end{tabular}




\section{EFFECTS OF SOME INDIGENOUS PLANT SEED EXTRACTS ON THE HAEMATOLOGY}

OF A PREDATORY FISH SINGHI HETEROPNEUSTES FOSSILIS (BLOCH)

With the variation in the seed extracts a decrease in the numbers of blood cells and the $\mathrm{Hb}$ contents were observed. The total numbers of $\mathrm{RBC}$ and $\mathrm{Hb}$ contents were less affected by D. innoxia seed extracts. Most of the effects were with $A$. rohituka seed extracts with greatly decreased number of RBC, WBC and $\mathrm{Hb}$ content. With the five seed extracts variation was in the order control < distilled water $<50 \%$ ethyl alcohol $<$ absolute ethyl alcohol extracts. Trend of toxicity on the basis of blood parameters was in the order: D. innoxia $<A$. auriculiformis $<P$. pinnata $<C$. viscosum $<A$. rohituka seed extracts.

The data of haematological parameters of control and treated fishes showed that the toxic property of the plant extracts induced several significant changes in the blood parameters of $H$. fossilis. The RBC and WBC counts, haemoglobin content, PCV, MCV and $\mathrm{MCH}$ values of blood of treated fishes decreased with all of the extracts which was proved by t-test which indicated that these five plant toxicants had haemolytic properties. Similar result was observed by Bhatt and Farswan (1992) in Barilius bendelesis treated with Aesculus indica, Engelhardtia colebrookiana, Lyonia ovalifolia and Zanthoxylem alatum plant extracts and Nasiruddin et al. (2001) treated with C. siamea and D. metel seed extracts in $H$. fossilis and C. punctatus. However, Agrawal et al. (1979), Srivastava and Agrawal (1979), Goel and Gupta (1985) and Nasiruddin et al. (2002) had reported similar decrease in mean values of RBC, WBC, Hb content and PCV values in Zinc, Nickel, Chromium, C. tora and A. lebbeck seed extract treated fishes but increase in the $\mathrm{MCV}$ and $\mathrm{MCH}$ values.

\section{Effects of the seed extracts on the blood cells of H. fossilis}

By determining the changes between the blood cells of control and treated fishes the extent of effects of different extracts of the experimental plant seeds were studied. The changes in the treated blood film indicated the evidences of damage.

\section{Control blood cells (Plate 1A)}

The size and shape of RBCs were large and oval with clear cell wall and centrally placed, almost regular shaped oval nuclei. Nuclei were sorrounded by thick broad rim of non granulated cytoplasm without any vacuolization. The size and shape 


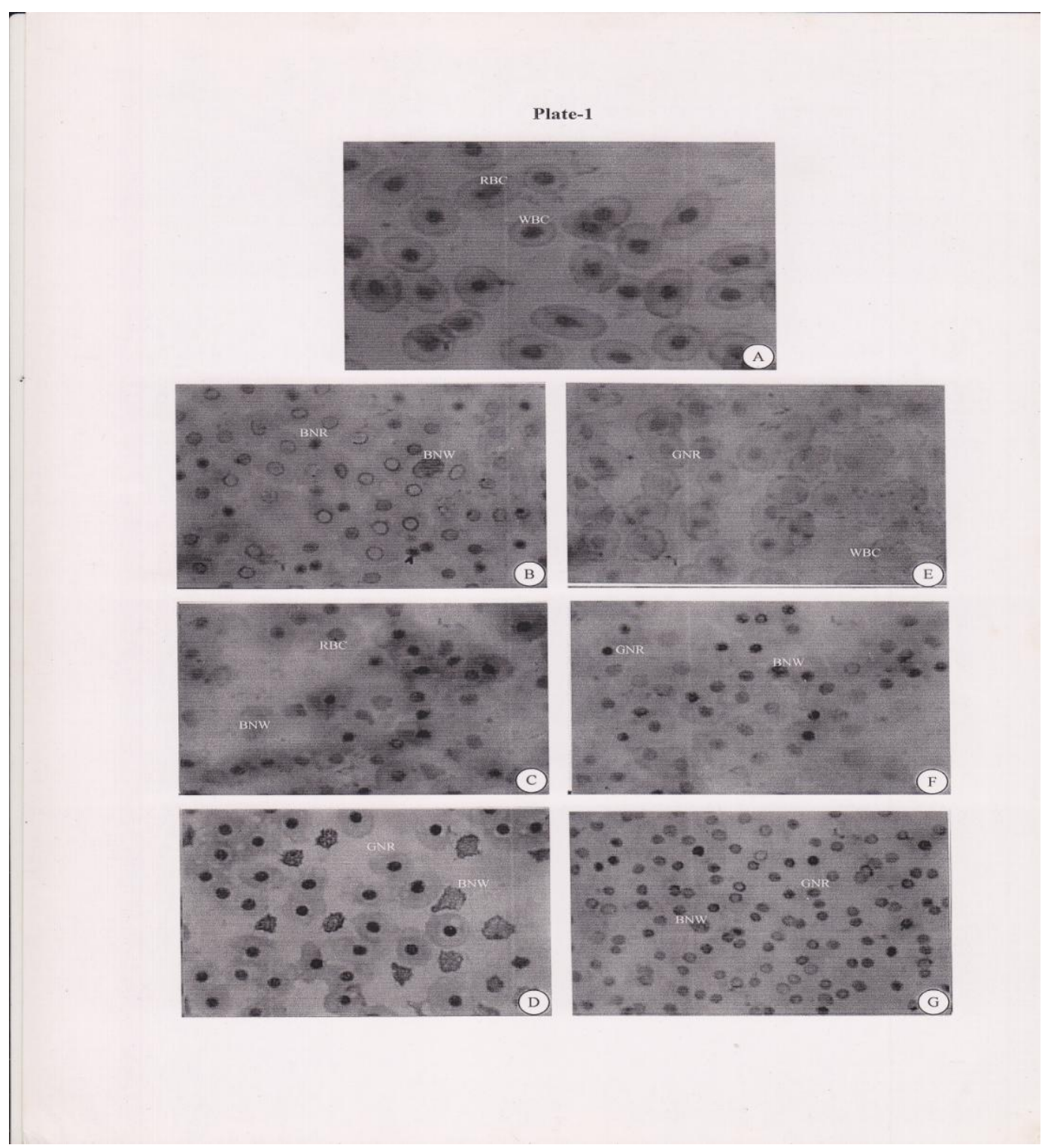

PLATE 1: SHOWING THE RED BLOOD CELLS (RBC) AND WHITE BLOOD CELLS (WBC) IN CONTROL (A), BARE NUCLEI OF RBC (BNR), GRANULATED NUCLEI OF RBC (GNR) AND BARE NUCLEI OF WBC (BNW) IN DISTILLED WATER (B), 50\% ETHYL ALCOHOL (C) AND ABSOLUTE ETHYL ALCOHOL (D) EXTRACTS OF DATURA INNOXIA AND DISTILLED WATER (E), 50\% ETHYL ALCOHOL (F) AND ABSOLUTE ETHYL ALCOHOL (G) EXTRACTS OF CLERODENDRUM VISCOSUM SEED TREATED BLOOD OF HETEROPNEUSTES FOSSILIS (X1000). 
EFFECTS OF SOME INDIGENOUS PLANT SEED EXTRACTS ON THE HAEMATOLOGY OF A PREDATORY FISH SINGHI HETEROPNEUSTES FOSSILIS (BLOCH)

of WBCs were mostly round or spherical with a large, round nucleus in the centre which was larger than the nuclei of RBCs.

Effects of extracts of D. innoxia seeds on the blood cells

The effect of $2000 \mathrm{ppm}$ of distilled water seed extract (Plate 1B) on the blood cells showed that the cell boundaries of RBCs were damaged. Some granulated nuclei of RBCs were seen and cell syncitium was evident. The nuclei of WBCs were deshaped and pyknotic. Bare nuclei of RBCs and WBCs due to cellular membrane damage were also seen. With $1500 \mathrm{ppm}$ of $50 \%$ ethyl alcohol extract (Plate 1C) both the RBCs and WBCs were swollen and deshaped but the nuclei of RBCs were shrunken and nuclei of WBCs were damaged. Clumping of $\mathrm{RBC}$ as well as syncitium in RBC matrix were observed to some extent. A few pyknotic nuclei of WBCs were seen. With $1000 \mathrm{ppm}$ of absolute ethyl alcohol extract (Plate 1D) the cytoplasmic boundaries of RBCs were damaged. Vacuoles were seen in the cytoplasm of RBCs. Cytoplasm of the RBCs became syncitial with the damage of cell membrane and the nuclei were shrunken. Much effects were seen in WBCs whereby cell wall disintegrated, cytoplasm disappeared and hence nuclei became bare, irregular, damaged and deshaped. Some of the nuclei of the WBCs were highly pyknotic.

\section{Effects of extracts of $C$. viscosum seeds on the blood cells}

With 150 ppm of distilled water seed extract (Plate 1E) the effect was seen as swollen RBCs. Boundary of some blood cells were damaged and granulated nuclei in some cells were observed. The nuclei of RBCs were swollen. The WBCs had also swollen cytoplasm with swollen nuclei. With 100 ppm of 50\% ethyl alcohol extract (Plate 1F), cell membrane of RBCs were damaged, cells swelled. Syncitium of RBC matrix occurred. Nuclei of RBCs were swollen and granulated. Some pyknotic and bare nuclei of WBCs were seen. With $50 \mathrm{ppm}$ of absolute ethyl alcohol extract (Plate 1G) clumping of RBCs as well as syncitium of RBC matrix were observed due to damage of cell membrane. Some bare nuclei of RBCs were seen. Nuclei of RBCs were shrunken and granulated. Cytoplasm of some WBCs disntegrated and nuclei of WBCs were shrunken, bare and pyknotic.

\section{Effects of extracts of A. rohituka seeds on the blood cells}

With $50 \mathrm{ppm}$ dose of distilled water seed extract (Plate 2A) deshaped RBCs with granulated nuclei were observed. Some granulated and bare nuclei were also seen. Some of the WBCs were damaged and the nuclei were deshaped and pyknotic. With $25 \mathrm{ppm}$ of 50\% ethyl alcohol extract (Plate 2B) the RBCs were congested and cell syncitium was mostly evident. Nuclei of RBCs were 
deshaped and some were swollen and granulated. Amongst some WBCs cytoplasm dissolved and greatly swollen and highly pyknotic nuclei were found in bared condition. With $10 \mathrm{ppm}$ absolute ethyl alcohol extract (Plate 2C) clumping of RBCs occurred to a much greater extent. Cell membrane was damaged as a result syncitium of RBC matrix was prominent. Nuclei of RBCs were shrunken, damaged, deshaped and granulated. The WBCs were swollen to some extent. Damage with mid vacuoles were also observed in some of the WBCs.

\section{Effects of extracts of A. auriculiformis seeds on the blood cells}

With $750 \mathrm{ppm}$ of distilled water seed extract (Plate 2D) changes in the blood cells were seen in swollen and greatly deshaped condition. Cell membrane was slightly damaged and nuclei were swollen. WBCs were swollen with pyknotic nuclei. Bare nuclei of RBCs were also observed. With 500 ppm of $50 \%$ ethyl alcohol extract (Plate 2E) most of the RBCs were swollen, with swollen and granulated nuclei. Clumping of RBCs were evident to some extent. Cell membrane of WBCs was slightly ruptured and nuclei were slightly swollen and pyknotic. With $250 \mathrm{ppm}$ of absolute ethyl alcohol extract (Plate 2F) the RBCs were greatly swollen. Clumping was observed to moderate extent. Some of the nuclei of RBCs were swollen and granulated. In a few cells cellular membrane was disintegrated and syncitium in RBC matrix was evident. WBCs were swollen and damaged with some bare, pyknotic and deshaped nuclei. 
EFFECTS OF SOME INDIGENOUS PLANT SEED EXTRACTS ON THE HAEMATOLOGY OF A PREDATORY FISH SINGHI HETEROPNEUSTES FOSSILIS (BLOCH)

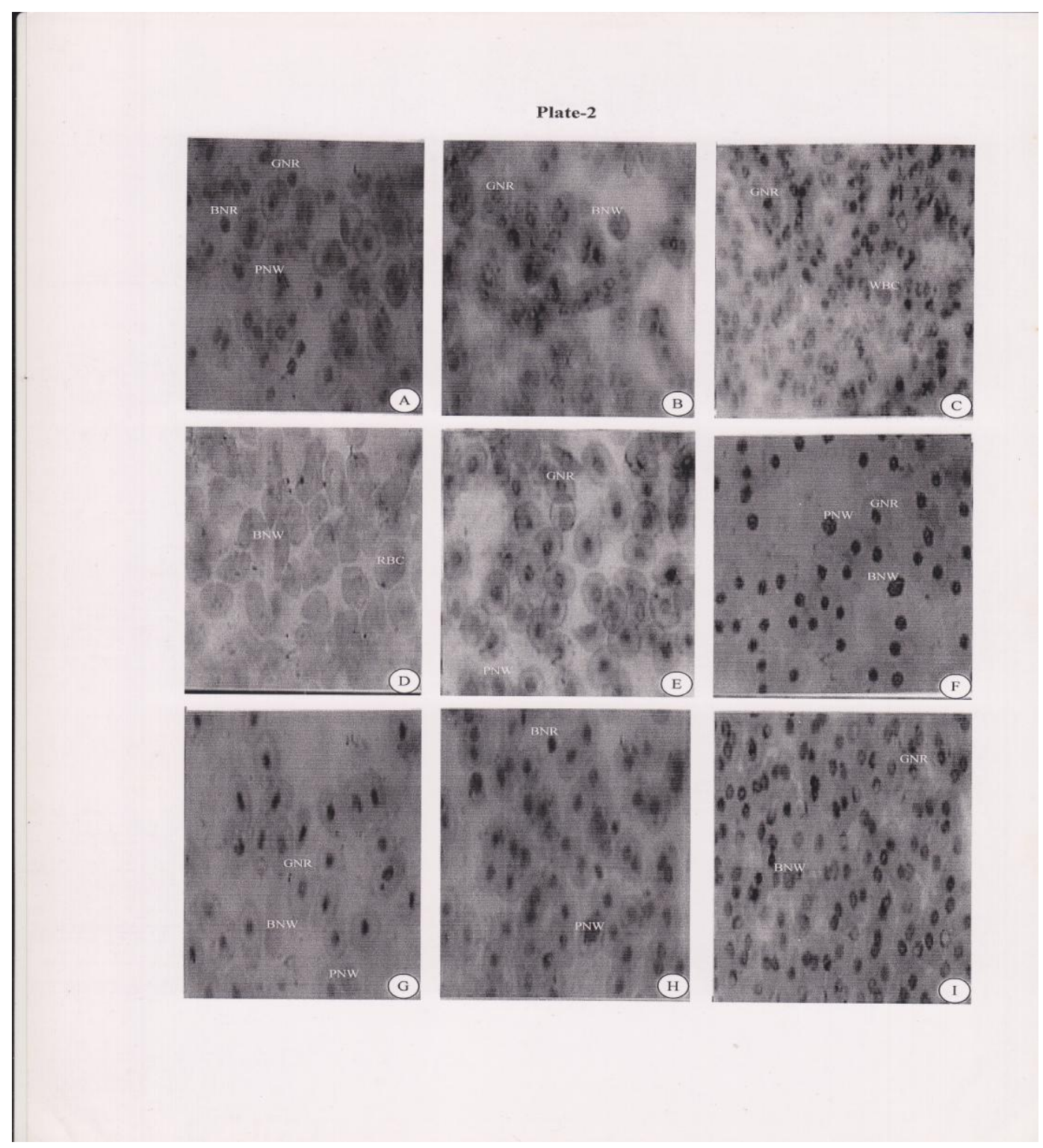

PLATE 2: SHOWING THE RED BLOOD CELLS (RBC), WHITE BLOOD CELLS (WBC), BARE NUCLEI OF RBC (BNR), GRANULATED NUCLEI OF RBC (GNR), BARE NUCLEI OF WBC (BNW) AND PYKNOTIC NUCLEI OF WBC (PNW) IN DISTILLED WATER (A), 50\% ETHYL ALCOHOL (B), ABSOLUTE ETHYL ALCOHOL (C) EXTRACTS OF AMOORA ROHITUKA, DISTILLED WATER (D), 50\% ETHYL ALCOHOL (E), ABSOLUTE ETHYL ALCOHOL (F) EXTRACTS OF ACACIA AURICULIFORMIS AND DISTILLED WATER (G), 
MUNIRA NASIRUDDIN et al.

50\% ETHYL ALCOHOL (H), ABSOLUTE ETHYL ALCOHOL (I) EXTRACTS OF PONGAMIA PINNATA SEED TREATED BLOOD OF HETEROPNEUSTES FOSSILIS (X1000).

\section{Effects of extracts of P. pinnata seeds on the blood cells}

With $250 \mathrm{ppm}$ of distilled water extract (Plate 2G) the effect was observed as swollen and deshaped RBCs. Cell membrane was ruptured in some of the RBCs. Nuclei were swollen, granulated and deshaped. Vacuoles were observed in the matrix of RBC cytoplasm. The WBCs were much affected with bare and pyknotic nuclei. In the RBC matrix slight cell syncitium was seen to occur. With $150 \mathrm{ppm}$ dose of 50\% ethyl alcohol extract (Plate 2H) the RBCs were observed in clumped condition. RBCs were swollen, round to oval with centrally placed swollen nuclei. Some bare nuclei were also seen. Vacuoles in the RBC cytoplasm were evident. Syncitium in RBC matrix were seen to a moderate extent. The WBCs were seen with damaged cell wall and pyknotic nuclei. A few WBCs were seen with thin cytoplasm sorrounding the swollen and damaged nuclei. With $50 \mathrm{ppm}$ dose of absolute ethyl alcohol extract (Plate 2I) the RBCs were densely clumped. RBCs were swollen with deshaped and granulated nuclei. Syncitium in the RBC matrix was very prominent. Nuclei of WBCs were pyknotic. Cell wall of some WBCs were disintegrated and hence the nuclei became bare.

As to dose ranges and haemolytic damages $A$. rohituka seed extracts were the most effective followed by $P$. pinnata and $C$. viscosum seed extracts. $A$. auriculiformis and $D$. innoxia seed extracts showed moderate effectivity. Effects on the blood cells were observed mainly as damages in RBCs resulting in changes with syncitium of RBC matrix. Cellular damage in WBCs resulted in bare and pyknotic nuclei. The order of effectivity in term of haematological damage is: $A$. rohituka $>C$. viscosum $>P$. pinnata $>D$. innoxia $>A$. auriculiformis seed extracts.The extent of effectivity of the extracts of the seeds were in the order control $<$ distilled water $<50 \%$ ethyl alcohol $<$ absolute ethyl alcohol extracts.

From the study of cell pictures, the blood smears of control fishes were without haemolysis and that of treated fishes showed damages such as rupture of cell membrane, shrunken or swollen RBCs, granulated nuclei of RBCs and pyknotic nuclei of WBCs, cellular damages resulting in bare nuclei of RBCs and WBCs, clumping of RBCs and syncitium of RBC matrix. Similar haemolytic nature of plant toxicants were also reported by Bhatt and Farswan (1992) and Nasiruddin et al. (2001, 2002). 
EFFECTS OF SOME INDIGENOUS PLANT SEED EXTRACTS ON THE HAEMATOLOGY OF A PREDATORY FISH SINGHI HETEROPNEUSTES FOSSILIS (BLOCH)

A significant decrease in the number of $\mathrm{RBC}$ after exposure to the toxicants was an indication of inhibited production of RBC caused by erythrocyte destruction (Mc Leay 1973). Decrease in the numbers of WBCs would indicate leucocystosis resulting in poor immune system to protect the fish against infections (Wedemeyer and Mc Leay 1981). Decrease in haemoglobin might be due to inhibition of $\mathrm{Hb}$ synthesis. The low PCV value also indicated anaemia (Wepner et al. 1992). Lower MCV and MCH values would also have similar explanations as to low PCV values.

The toxic substances in the medium caused differences in haemolytic activity. The active ingredients of the five indigenous plant seeds influenced the toxicity on the haemopoesis process in $H$. fossilis. This suggested that the physiology of the fishes was disturbed to some extent resulting in death of the fishes while being toxified with these plant seed extracts.

\section{REFERENCES}

AGBON, A.O., OMONIYI, I.T. AND TEKO, A.A. 2002. Acute toxicity of tobacco (Nicotiana tobaccum) leaf dust on Oreochromis niloticus and haematological changes resulting from sub-lethal exposure. J. Aqua. Sci. 17: 5-8.

AGRAWAL, S.J., SRIVASTAVA, A.K. AND CHAUDHURY, H.S. 1979. Haematological effect of Nickel on a freshwater teleost Colisa fasciatus. Acta. Pharmacol. Toxicol. 45: 215-217.

AGRAWAL, V.P., GOEL, K.A. AND SHARMA, S.D. 1985. Haematological characteristics of Clarias batrachus under the metallic stress of hexavalent chromium. Ind. J. Fish. 32(2): 272-275.

ALLEN, P. 1993. Effects of acute exposure to Cadmium (II) and Lead (II) chloride on the haematological profile of Oreochromis aureus (Steindachner). Comp. Biochem. Physiol. 105C: 213-217.

AMERICAN PUBLIC HEALTH ASSOCIATION (APHA). 1976. Standard methods for the examination of water and waste water. $14^{\text {th }} \mathrm{Ed}$. Washington D.C. 1193PP

ASHRAF, R.A., YADAV, M., KUMAR, D. AND YADAV, B.N. 2003. Toxicity effects of Cadmium chloride on some haematological parameters in two air-breeding fishes. Bulletin of Pure and Applied Sciences 22A(1): 69-72.

BHATT, J.P. AND FARSWAN, Y.S. 1992. Haemolytic activity of piscicidal compounds of some plants to a fresh water fish Barilius bendelisis (Ham.) J. Environ. Biol. 13(4): 333-342. 
MUNIRA NASIRUDDIN et al.

BLAXHALL, P.C. 1972. The haematological assessment of the health of freshwater fish. J. Fish Biol. 4: 593-604.

DHEER, J.M.S., DHEER, T.T. AND MAHAJAN, C.L. 1986. Haematological and haemopopoietic response to Sodium Chloride stress in a freshwater air breathing fish, Channa punctatus (Bloch). J. Fish Biol. 29: 119-128.

FAFIOYE, O.O., ADEBISI, A.A. AND FAGADE, S.O. 2004. Toxicity of Parkia biglobosa and Raphia vinifera extracts on Clarias gariepinus juveniles. Afr. J. Biotechnol. 3: 627-630.

GOEL, K.A. AND GUPTA, K. 1985. Haematobiochemical characteristics of Heteropneustes fossilis under the stress of Zinc. Ind. J. Fish. 32(2): 256-260.

HYMAVATHI, V. AND RAO, L.M. 2000. Effect of sublethal concentrations of Lead on the haematology and biochemical constituents of Channa punctata. Bulletin of Pure and Applied Sciences 19A(1): 1-5.

MCLEAY, D.J. 1973. Effect of a 12-hr and 25-day exposure to Kraft pulp mill effluent on the blood and tissue of juvenile coho salmon (Onchorynchus kisutch). J. Fish. Res. Bd. Can. 30: 395-400.

NASIRUDDIN, M., AZADI, M.A. AND TABASSUM, F. 2001. Haemolytic effects of seed extracts of Cassia siamea (L.) and Datura metel (L.) on Heteropneustes fossilis (Bloch) and Channa punctatus (Bloch). Bangladesh J. Zool. 29(1): 19-28.

NASIRUDDIN, M., AZADI, M.A., JAHAN, A. AND CHOWDHURY, R. 2002. Haemolytic effects of Cassia tora (L.) Benth and Albizzia lebbeck (L.) Benth seeds on Heteropneustes fossilis Bloch and Channa punctatus Bloch. Bangladesh J. Zool. 30(1): 11-19.

OMONIYI, I., AGBON, A.O. AND SODUNKE, S.A. 2002. Effect of lethal and sub-lethal concentrations of tobacco (Nicotiana tobaccum) leaf dust extracts on weight and haematological changes in Clarius gariepinus (Burchell). Journal of Applied Sciences and Environmental Management. 6(2): 37-41.

PANDEY, P.K., SINGH, N.K., CHOUDHARY, B.P. AND THAKUR, G.K. 1981. Effect of organophosphorous insecticide, Malathion, on the haematology of Channa punctatus (Bloch). J. Inland Fish. Soc. India 13(2): 120-121.

RAPHAEL, S.S. 1983. Lynch'sMedical Laboratory Technola. W. B. Saunders Company. Philadelphia, London. 
EFFECTS OF SOME INDIGENOUS PLANT SEED EXTRACTS ON THE HAEMATOLOGY

OF A PREDATORY FISH SINGHI HETEROPNEUSTES FOSSILIS (BLOCH)

SEN, G., BEHERA, M.K., AND PATEL, P. 1992. Effects of En on haematobiochemical parameters of Channa punctatus. J. Ecotoxicol. Environ. Monit. 2(2): 89-92.

SRIVASTAVA, A.K. AND AGRAWAL, S.J. 1979. Haematological anomalies in a freshwater teleost Colisa fasciatus on acute exposure to Cobalt. Acta.

Pharmacol. et. Toxicol. 49: 197-199.

VOSYLIENE, M.Z. 1996. Haematological parameters of rainbow trout (Oncorhynchus mykiss) during short-term exposure to Copper. Ekologija 3: 12-18.

VOSYLIENE, M.Z. 1999. The effect of heavy metals on haematological indices of fish (survey). Acta Zoologica Lituanica Hydrobiologia 9(2): 76-82.

WEDEMEYER, G.A. AND MCLEAY, D.J. 1981. Methods for determining the tolerance of fishes to environmental stressors. In: Pickering, A.D. (ed.). Stress and Fish. Academic Press, New York. pp 247-255.

WEPNER, V., VAN VAUREN, J.H.J. AND DU PREEZ, H.B. 1992. The effect of hexavalent chromium at different $\mathrm{pH}$ values on the haematology of Tilapia sparrmani (Cichlidae). Comp. Biochem. Physiol. 161C(2): 375-381.

Manuscript received on 15.02.2010; Accepted on 29.09.2011

The Chittagong University Journal of Biological Sciences, Vol. $6(1 \&$ 2). Page No. 